\title{
Protecting Children with AIDS Against Arbitrary Exclusion from School
}

Ryan White, a fourteen-year-old boy in Kokoino, Indiana, was excluded froin school for over a year because he has acquired immune deficiency syndroine (AIDS). ${ }^{1}$ Yet there is broad consensus among medical experts that the disease cannot be transmitted by casual contact. ${ }^{2}$

1. N.Y. Times, Feb. 14, 1986, at A12, col. 2. Ryan was readmitted to school after parents of other children dropped their legal opposition due to high expenses. The parents intend to seek legislation to keep Ryan out of school. L.A. Times, Aug. 26, 1986, at 18, col. 1.

Similarly, Channon Phipps, an eleven-year-old boy in Orange County, California, was excluded from school for over a semester because he has AIDS. L.A. Times, Feb. 6, 1986, at 32, col. 1. Some other children excluded because they have AIDS have chosen not to sue, and have stayed home. See, e.g., L.A. Daily J., Oct. 15, 1985, at 20, col. 3 (children in Redondo Beach and Carmel, California); N. Y. Times, Sept. 18, 1985, at A20, col. 3 (triplets in Miami, Florida).

2. See, e.g., Recommendations for Preventing Transmission of Infection with Human TLymphotropic Virus Type III/Lymphadenopathy-Associated Virus in the Workplace, 34 CENTERS FOR Disease CONTROL: MORBIDITY \& MORTALITY WEeKLY REP. 682 (1985). AIDS is a disease that causes the body's immune system to collapse. A. GiUdicI \& W. CHECK, THE TRUTH ABOUT AIDS 2 (1985). Persons with AIDS, having no immunity, become ill with opportunistic infections. Id. at 22. Persons with AIDS usually do not live more than a few years after discovering that they have the disease. Comment, AIDS: Does it Qualify as a "Handicap" Under the Rehabilitation Act of 1973?, 61 Notre DAME L. Rev. 572, 575 (1986) (“Once afflicted, the patient's prognosis for survival is grim-the two year mortality rate for the disease is close to ninety percent. Over seventyfive percent of all patients diagnosed as having AIDS before January 1984 are known dead." (footnotes omitted)).

The virus thought to be the cause of AIDS, human T-cell lymphotropic virus Type III (HTLVIII) or lymphadenopathy-associated virus (LAV), Centers for Disease Control, Department of Health and Human Services, Revision of the Case Definition of Acquired Immunodeficiency Syndrome for National Reporting—United States, 103 ANN. INTERN. MED. 402 (1985), has been found in "blood, semen, saliva, tears, urine, cerebrospinal fiuid, brain tissue and cervical secretions and is likely to be present in other body fluids, secretions and tissues." 35 CENTERS FOR Disease CONTROL: MORBIDITY \& MORTALITY WEEKLY REP. 541 (1986). Medical experts have concluded that the virus can only be transmitted by such means as intimate sexual contact, sharing infected needles, or using infected blood products, as during blood transfusions. Recommendations for Preventing Transmission of Infection with Human T-Lymphotropic Virus Type III/ Lymphadenopathy-Associated Virus in the Workplace, supra, at 682.

"As of December 8, 1986, physicians and health departments in the United States had reported 28,098 (27,704 adults and 394 children) meeting the AIDS case definition for national reporting. Of these patients, 15,757 ( $56 \%$ of adults and $61 \%$ of children) are known to have died, including over 79\% of those patients diagnosed before January 1985." 35 CENTERS FOR DISEASE CONTROL: MORBIDITY \& MORTALITY WEEKLY REP. 757 (1986).

The Public Health Service states that 1 million to 1.5 million persons have been infected by the AIDS virus. Of these, it estimates that 20\% to 30\% will develop AIDS by 1992. Pear, Rights Laws Offer Only Limited Help on AIDS, U.S. Rules, N.Y. Times, June 23, 1986, at A1, col. 2. The Centers for Disease Control projects a cumulative case total of 270,000 by 1991. 35 CENTERS FOR DISEASE CONTROL: MORBIDITY \& MORTALITY WEEKLY REP. 765 (1986). "Currently reported cases have 
Although parents of healthy children have legitimate expectations that their children will be safe at school, there is great danger that children with AIDS will be unnecessarily excluded from school to their detriment because people do not understand the facts about the disease. Children with AIDS, like Ryan, are feared unjustifiably and immersed in controversy through no fault of their own. ${ }^{3}$ Depriving them of an education with their peers will only further diminish their chances of overcoiming prejudices and hiving normal lives since the socialization process to which children are exposed in school teaches them to interact with others and helps them to becoine productive members of society. ${ }^{4}$ Regardless of how long these children may live, they have the same right to education as other children and hopefully a treatınent or cure will soon exist, enabling then to hive healthy lives. ${ }^{5}$

This Comment discusses who should decide whether a child with AIDS should be excluded from school and what criteria the deci-

resulted from HTLV-III/LAV exposure up to 7 years before diagnosis; the possibility of longer incubation periods cannot be excluded." Id. at 20 .

3. D. ALTMAN, AIDS IN THE MIND of AMERICA, 58-65; Silas, Is School for Alli, 71 A.B.A. J. 18 (1985) (unknowns about AIDS prompting many school districts to take precautions); Barnes, AFRAIDS, NEw REPUBLIC, Oct. 14, 1985, at 7-10 (acute fear of AIDS leading to hysteria in school districts); N.Y. Times, April 11, 1986, at A14, col. 1 (27 students stay home on Ryan White's first day back at school); Minneapohis Star \& Trib., Oct. 26, 1985, at 9A, col. 1 ("More than 60 percent of the pupils at an elementary school in Washington Borough, New Jersey stayed away from school for a second day as parents protested the presence of a 9-year-old boy whose sister has AIDS-related complex."); Russell, AIDS Stirs Public Concern But Not Panic, Survey Says: Poll Finds Wide Knowledge About Disease, Wash. Post, Sept. 26, 1985, at A1, col. 5 (substantial minority of peoplc surveyed believe AIDS is as contagious as the common cold and that persons with AIDS should be quarantined); Eckholm, Poll Finds Many AIDS Fears That the Experts Say Are Groundless, N.Y. Times, Sept. 12, 1985, at B11, col. 3 (about half the persons surveyed believe AIDS can be transmitted through casual contact); Rohter, 11,000 Boycott Classes in AIDS Protest, N.Y. Times, Sept. 10, 1985, at B1, col. 2 (11,000 students boycott school to protest city's decision to allow one child with AIDS to attend school).

4. Courts and other authorities have recognized the importance of cducation to socialization. Brown v. Board of Educ., 347 U.S. 483, 493 (1954) ("In these days it is doubtful that any child may reasonabiy be expected to succeed in life if he is denied the opportunity for an education."); Plyler $v$. Doe, 457 U.S. 202, 222 n.20 (1982); New York State Ass'n for Retarded Children v. Carey, 466 F. Supp. 479, 485 (E.D.N.Y. 1978) (association with normal students is the primary means by which mentally retarded students improve and develop); Halderman v. Pennhurst State School and Hosp., 446 F. Supp. 1295, 1323 (E.D. Pa. 1977) (segregation of retarded students in isolated institutions violates equal protection clause); Hairston v. Drosick, 423 F. Supp. 180, 183 (S.D.W. Va. 1976) (“A child's chance in this society is through the educational process. A major goal of the educutional process is the socialization process that takes place in the regular classroom, with the resulting capability to interact in a social way with one's peers. It is therefore imperative that every child receive an education with his or her peers insofar as it is at all possible."); The Effects of Segregation and the Consequences of Segregation: A Social Science Statement, 37 MiNN. L. REv. 427, 432 (1953) (reprinting appendix to brief in Brown v. Board of Education) (Segregation distorts social reality and increases mutual suspicion, distrust and hostility).

5. See L.A. Daily J., Sept. 22, 1986, at 1. col. 5 (new drug AZT shows "great promise for prolonging life" of persons with AIDS); L. Altman, Physicians Describe Apparent Recovery of an A1DS Patient, N.Y. Times, June 25, 1986, at A1, col. 6. 
sionmaker should consider. Current statutory and constitutional provisions are inadequate to protect children with AIDS and their classinates. This Comment argues that the judgment of whether a child with AIDS presents a danger to others at school should be made by a detached board of physicians. These physicians can make a more accurate assessment of the risks than local school boards. Part I traces the history of quarantine and isolation as methods of curbing the spread of diseases and summarizes soine significant early cases which limit states' power to restrict individual hiberty for the protection of the public health. Part II argues that existing statutory and constitutional provisions have not provided judges with appropriate ways to inake their decisions. Part III proposes a federal statute which enables states to establisi administrative boards to decide whether to permit a child with AIDS to attend school.

Although this Comment focuses upon AIDS, it also discusses communicable diseases that are not fatal and that are more easily transmittable than AIDS. ${ }^{6}$ Examining how courts and legislatures have treated children with other commumicable diseases is instructive in deciding how to treat children with AIDS. In addition, the statute proposed in Part III includes other communicable diseases that are fatal within a short period of time because of the particularly tragic and intolerable probleins raised by those diseases.

\section{I \\ LEgAL BACKGROUND OF QUARANTINE AND ISOLATION}

Part I of this Comment briefly describes the history of quarantine and isolation as methods of preventing the spread of disease. It also suinmarizes some sigmificant early cases that set forth himits on states' power to quarantine and isolate citizens for the public good. Finally, Part I discusses a number of early cases that addressed whether the state could exclude children with communicable diseases froin school and concludes that the early cases are not persuasive as current legal authority.

\section{A. Background}

The history of quarantine and isolation as inethods of preventing the spread of disease sheds hight on whether and under what circunistances children with cominunicable diseases should be excluded from schools. The history of quarantine and isolation reflects the tension between the

6. A disease is communicable when it can be transmitted from one person to another. AIDS can only be transmitted through blood or the exchange of other body fluids, primarily by sharing infected needles or sexual intercourse. See supra note 2 . Other diseases are transmitted more easily than AIDS. For example, tuberculosis, Smith, Schoomaker \& Kleinman, High Court Eyed for Guidance on AIDS as Handicap, Legal Times, June 30, 1986, at 35, col. 1, and hepatitis B, Comment, supra note 2, at 580 n.51 (1986), are both more easily communicated than AIDS. 
state's interest in protecting the public and individual liberty. For centuries, because of the public's fear of communicable diseases, quarantine and isolation were accepted methods of preventing the spread of disease. But even before quarantined individuals began claiming that they were being isolated unjustly, there was disagreement about both the liumanity and the effectiveness of these inethods in protecting the public from communicable diseases. ${ }^{7}$ Historically, quarantine and isolation were used to contain easily transmittable diseases such as sinall pox and bubonic plague.

In the early Middle Ages leprosy spread through Europe, leaving thousands severely deformed. ${ }^{8}$ The Church tried to curtail spread of the disease by limiting the freedom of lepers to associate with others. ${ }^{9}$ In 644, the Lombard King ordered the isolation of all lepers. ${ }^{10}$ Persons with leprosy were deprived of all of their civic rights, cast out, and considered dead since there was no known cure for the disease. ${ }^{11}$

In the fourteenth century the bubomic plague, or "Black Death," spread rapidly through Europe. ${ }^{12}$ As with leprosy, the primary method of containing the epidemic was isolation of those with the disease. ${ }^{13}$ Persons suspected of having bubonic plague were reported to municipal authorities and examined. ${ }^{14}$ If they were in fact infected, they, and everyone with whom they had come in contact, were then isolated in their houses. ${ }^{15}$ In 1374, the Duke of Milan ordered all persons with the plague reinoved from the city to a field where they would either die or recover. ${ }^{16}$ European communities that had not yet been infected quarantined incoming ships to prevent entry of the plague. ${ }^{17}$ All suspected persons were isolated and observed until it was established that they were not infected. ${ }^{18}$ The port town of Venice instituted the first such quarantine in $1348 .{ }^{19}$

7. C. Rosenberg, The Cholera Years, 79-81, 93, 168 (1962). (Although "prevailing medical opinion was decidedly hostile" to quarantine in 1832, the public believed in it and, as a result, "not to have enforced quarantines would have been politically suicidal.")

8. G. Rosen, A History of Public Health 63 (1985).

9. Id. at 64 .

10. Id.

11. Id. "The awful finality of exclusion from the human community was symbolized by an enactment of the funeral service involving the participation of the leper. He was clad in a shroud, the solemn mass for the dead was read, earth was thrown upon him, and he was then conducted by the priests, accompanied by relatives, friends, and neighbors to a hut or leprosarium outside the confines of the community." Id. at 65 .
12. Id. at 62 .
13. Id. at 67 .
14. Id.
15. Id.
16. Id. at 68 .
17. Id. at 67-68.
18. Id. at 68 .
19. Id. 
American colonists brought with them from Europe their belief that quarantime and isolation were effective methods of preventing the spread of disease. By 1720, Massachusetts had established an elaborate quarantine system. ${ }^{20}$ Boston officials were given power to isolate anyone who had " the plague, small pox, pestilential or malignant feaver (sic), or other contagious sickness, the infection whereof may probably be communicated to others." "21 At the beginning of an outbreak of an infectious disease, the town officials would put guards outside infected houses to make sure no one went im or came out. ${ }^{22}$ In the early 1800's, "publicly enforced measures for control of [contagious diseases] were largely limited to isolation and quarantine." ${ }^{23}$ In 1884, the Massachusetts legislature passed a law requiring doctors and family members to report to local officials any cases of "small pox, diphtheria, or scarlet fever, or any other disease dangerous to the public health." 24 In addition, children of famihies im which a member had small pox, diphtheria or scarlet fever could not attend public school until two weeks after the family member witl the disease had recovered or died. ${ }^{25}$

During both World Wars, the United States military quarantined tens of thousands of prostitutes and soldiers to prevent the spread of venereal diseases among American troops. ${ }^{26}$ Between 1918 and 1920, federal officials confined more than 18,000 women to institutions to stop them from spreading the diseases. ${ }^{27}$ "Most" of these "detention houses and quarantine hospitals ... did not permit visitors. . . . The need for strict quarantine was taken seriously. Barbed wire and guards secured many of the institutions."28 In France the military segregated the infected men in special camps. Of the approximately two million men in the American Expeditionary Forces, 18,000 missed action each day because of venereal disease. ${ }^{29}$

\section{B. Court Response to Quarantine}

At the turn of the century, individuals began to bring suit in court in response to isolation by the state. Imitially, American courts held that

20. J. Blake, Public Health in the Town of Boston 36 (1959).

21. Id. at 33 .

22. Id. at 75 .

23. B. Rosenkrantz, Public Health and the State 2-3 (1972); accord, Rosenberg, supra note 7, at 19 (New York City's "Board of Health was charged with the administration and enforcement of the City's public health regulations which, in practice, consisted almost entirely of enforcing quarantine.").

24. B. ROSENKRANTZ, supra note 23 , at 110.

25. Id.

26. A. Brandt, No Magic Bullet 89, 116, 167 (1985).

27. Id. at 89 .

28. Id.

29. Id. at 116 . 
the states' power to quarantine individuals in order to protect the public health fell under the states' police power. In the influential 1905 case, Jacobson v. Massachusetts, ${ }^{30}$ the United States Supreme Court upheld a state statute requiring the vaccination of all inhabitants of a city where small pox was prevalent on the ground that the state's police power embraced all reasonable regulations relating to matters affecting the health and safety of its citizens.

Following Jacobson, courts generally deferred to boards of health, ${ }^{31}$ but required that the state health departments' actions not be arbitrary and unreasonable. In In re Smith, ${ }^{32}$ for example, the court held that city health officials acted beyond their statutory authority when they tried to quarantine two dehverymen who refused to be vaccinated against small pox. The court held that the dehverymen could not be quarantined because they were not infected and had not been exposed to smallpox, stressing that only the possibility that they could become infected had been alleged: "Such allegations fall far short of stating facts upon which the commissioner of health would be authorized to take such drastic measures as to effect the imprisonment of citizens by quarantining them in their houses. ... It was necessary to [the commissioner's] jurisdiction that the danger should actually have existed." 33

Another case that identified limits on health departments' police power was People v. Robertson. ${ }^{34}$ Although the court upheld the forced isolation of a healthy woman who was a typhoid carrier, it articulated important limitations on the power of health authorities to make and enforce regulations. The court stressed that

while the courts will not pass upon the wisdom of the means adopted to restrict and suppress the spread of contagious and infectious diseases, they will interfere if the regulations are arbitrary and unreasonable.... Where danger of an epidemic actually exists, health and quarantine regulations will always be sustained by the courts; but the health regulations are all sustained on the law of necessity, and when the necessity ceases the right to enforce the regulations ceases. ${ }^{35}$

Courts also limited the state's police power on equal protection

30. 197 U.S. 11 (1905).

31. See, e.g., Varholy v. Sweat, 153 Fla. 571, 575-76, 15 So. 2d 267, 269 (1943); People v. Robertson, 302 I11. 422, 426-27, 134 N.E. 815,817 (1922).

32. 146 N.Y. 68,40 N.E. 497 (1895).

33. Id. at 77, 40 N.E. at 499; see also Wragg v. Griffin, 185 Iowa 243,170 N.W. 400 (1919) (health board exceeded its statutory authority by detaining an individual who was merely suspected of being guilty of lewd and vicious cohabitation and of having a venereal disease); Ex Parte Dillon, $44 \mathrm{Cal}$. App. 239, 186 P. 170 (1919) (health department went beyond its statutory authority by detaining an individual who was arrested for having sexual intercourse with a person to whom he was not married and by requiring the individual to submit to a venereal disease test).

34. 302 Ill. 422,134 N.E. 815 (1922).

35. Id. at $432-33,134$ N.E. at 819 (emphasis added) (citations omitted). 
grounds. In Jew Ho v. Williamson, ${ }^{36}$ San Francisco health officials discovered nine fatal cases of what they diagnosed as bubonic plague in a priniarily Chinese neighborhood. They quarantined a twelve-squareblock area in which about ten thousand Asians lived. The city prohibited persons from entering or leaving the area, but allowed all persons within the area to nove freely. The Ninth Circuit held that the quarantine as enforced violated the equal protection clause of the fourteenth aniendinent because it was apphed discriminatorily and because the vast scope of the quarantine was not rationally related to preventing the spread of the disease. ${ }^{37}$

The historical instances of quarantine and the early response of the courts lend insight to the problem of excluding children with AIDS froni school. The early cases are of limited instructive value when applied to the case of children with AIDS who are excluded from school, however, because these cases involved casually transmitted diseases such as smallpox and bubonic plague. The state's power to quarantine people with AIDS presents a different set of problems since the disease cannot be casually transmitted.

\section{Early Cases Involving Children with Communicable Diseases}

Few cases have addressed the issue of whether the state can exclude children with communicable diseases from public school. The cases that have confronted the issue fall imto two readily observable groups. The first group, decided in the early decades of the 1900 's, denionstrates that courts did not have clear standards by which to set himits on officials' discretion. The second group of cases, being decided today, illustrates that the statutory and constitutional provisions relied upon by courts are inappropriate for children with communicable diseases. ${ }^{38}$

In the early part of the 1900 's courts assumed that if a child was infected with or had been exposed to a communicable disease, school officials had the authority to exclude the child from public school under the police power so long as their actions were not arbitrary and unreasonable. ${ }^{39}$ In Duffield v. School District of Williamsport, ${ }^{40}$ the Pennsylvamia Supreme Court held that the board of school directors acted within its statutory authority in excluding a child who refused to

36. 103 F. 10 (9th Cir. 1900).

37. Id. at 23-24.

38. These cases are described in Parts II and III, infra.

39. Potts v. Breen, 167 I11. 67, 47 N.E. 81 (1897); Stone v. Probst, 165 Minn. 361, 206 N.W. 642 (1925); Duffield v. School District of Williamsport, 162 Pa. 476, 29 A. 742 (1894); see, e.g., Carr v. Inhabitants of Dighton, 229 Mass. 304, 118 N.E. 525 (1918) (town school committee can exclude children with head lice unless action is taken in bad faith); see also supra text accompanying notes 30-37 (discussing police power in cases of quarantine).

40. 162 Pa. 476, 29 A. 742 (1894). 
comply with a vaccimation regulation. The court held that the board's authority followed from its power to exclude a child with a communicable disease:

It is conceded that the board might rightfully exclude the [child] if he was actually sick with, or was just recovering from, the smallpox. Though he might not be affected by it, yet, if another member of the same family was, the right to exclude him, notwithstanding he might be in perfect health, would be conceded. How far shall this right to exclude one for the good of many be carried? That is a question addressed to the official discretion of the proper officers, and, when that discretion is honestly and impartially exercised, the courts will not interfere. ${ }^{41}$

Three years after Duffield, the Illinois Supreme Court faced the vaccination issue in Potts v. Breen ${ }^{42}$ and also addressed in its reasoning whether officials could exclude children with communicable diseases. The court concluded that the board of health could temporarily exclude children who had been exposed to smallpox in its exercise of the police power delegated to it. There were limits on the power that could be exerted by the board-since the board's power derived from the state's pohice power, local officials could only exclude children from school if it was necessary to protect the public health. ${ }^{43}$

The last of these early cases, Stone v. Probst, ${ }^{44}$ squarely addressed whether officials could exclude children with communicable diseases from scliool. A six-year-old girl, excluded from scliool for having a sore throat, was required to submit to the school board a negative throatculture report and certificate from a doctor in order to be readmitted. She objected to the requirements based upon her religious beliefs as a Christian Scientist. The Minnesota Supreme Court disagreed with her contention that such requirements should be operative only for a reasonable time during an epidemic:

The teacher could not be expected to determine if it was ordinary or streptococcic or the early stage of some other contagious or infectious children's disease. We must recognize that one child may quickly spread a disease among the many children it comes in contact with in school. It seems more reasonable to us to have the rules applicable in preventing as well as in controlling an epidemic. ${ }^{45}$

The Stone court thus gave school boards a great deal of latitude by upholding the exclusion of the child.

The early cases did not use consistent or adequate standards in defining the limits on scliool boards' authority to exclude children with

\footnotetext{
41. Id. at $484,29 \mathrm{~A}$. at 743 .

42. 167 111. 67,47 N.E. 81 (1897).

43. Id. at 75,47 N.E. at 84 .

44. 165 Minn. 361, 206 N.W. 642 (1925).

45. Id. at 365, 206 N.W. at 644 .
} 
communicable diseases. Although these cases recognized school officials' authority to exclude, the Potts court would have limited this power to times of necessity, ${ }^{46}$ while the Stone court seenied to give school officials broad discretion to exclude such children. ${ }^{47}$

The early cases dealing with quarantine and exclusion of children with communicable diseases fronı school are of limited value as applied to children with AIDS. The early quarantine cases are not persuasive as current legal authority because they involved casually transınitted diseases and therefore do not justify quarantine of persons with AIDS, which is not easily communicated. The early cases excluding children froni school are also unhelpful because each of the fifty states has different standards and federal common law is virtually nonexistent. This leads to disparate treatnient of similar cases, which would be decreased if uniform federal standards were impleinented. In addition, to get relief under the common law, children who are excluded front school must go through a lengthy and burdensome court process.

\section{II \\ CURRENT STATUTORY AND CONSTITUTIONAL REMEDIES For CHILDREN With CoMmunicable Diseases}

In the past decade courts have decided a second group of cases involving children with communicable diseases. ${ }^{48}$ These recent cases have rehed upon various statutory and constitutional provisions to determime the scope of health and school officials' authority. ${ }^{49}$

46. Potts v. Breen, 167 Ill. at 74,47 N.E. at 84.

47. See supra text accompanying note 45 .

48. During the approximately 50 years between the early cases discussed in the preceding Part and the more recent ones discussed in this Part, the courts did not decide any cases directly addressing officials' authority to exclude children with commuricable diseases from school. During those years courts upheld many local ordinances that required children to be vaccinated before attending school. See, eg., Zucht v. King, 260 U.S. 174 (1922); Allen v. Ingalls, 182 Ark. 991, 33 S.W.2d 1099 (1931); Pierce v. Board of Educ., 219 N.Y.S.2d 519, 30 Misc. 2d 1039 (1961); Mack v. Board of Educ., 1 Ohio App. 2d 143, 204 N.E.2d 86 (1963).

Two explanations may account for the lack of cases during this period. First, school officials' authority to exclude children may have bccome an accepted means of protecting the public health. Second, advances in the field of medicine reduced the number of diseases considered dangerous in a school setting and the amount of time for which children with the diseases were excluded. When children began to show up at school with diseases such as AIDS or herpes for which the modes and ease of transmission were uncertain, the community no longer had confidence in school officials' assessment of the danger. This could have resulted in an increase in the number of cases brought.

49. Before the introduction of statutory provisions, children excluded from school had federal causes of action asserting that the state had exceeded its authority in its exercise of its police power. Comment, Fear Itself: AIDS, Herpes and Public Health Decisions, 3 YALE L. \& PoL'y Rev. 479, 490 \& n.49 (1985).

Two recent cases, Phipps v. Saddleback Valley Unified School Dist., No. 47-49-81 (Cal. Super. Ct. Feb. 28, 1986) and Coopennan v. Board of Educ., No. C-5150-85E (N.J. Super. Ct. Ch. Div. Oct. 31, 1985), rest upon state law. In Phipps, the relevant state statute pernnitted the "governing 
In some of the recent cases, the courts based their decisions upon more than one statutory or constitutional provision. New York State Association for Retarded Children v. Carey $^{50}$ and District 27 Community School Board v. Board of Education ${ }^{51}$ rehed upon the Rehabilitation $\mathrm{Act}^{52}$ and upon the fourteenth amendment's equal protection clause. ${ }^{53}$ In Council Bluffs Education Association v. Council Bluffs Community School District, ${ }^{54}$ Ely v. Howard County Board of Education, ${ }^{55}$ and White v. Western School Corp. ${ }^{56}$ however, the courts relied solely upon the Education for All Handicapped Children Act. ${ }^{57}$

The results of these cases have been varied. While most of the children were readmitted to school, some of them were excluded for long periods of time. This Part describes each of these avenues for relief, beginning with the EAHCA, and argues that, as with the legal standards articulated in earlier cases, existing statutory and constitutional provisions are not adequate or appropriate for deciding these cases.

\section{A. The Education for All Handicapped Children Act}

In enacting the EAHCA, Congress declared:

It is the purpose of this chapter to assure that all handicapped children have available to them . . . a free appropriate public education which emphasizes special education and related services designed to meet their unique needs, to assure that the rights of handicapped children and their parents or guardians are protected, to assist States and localities to provide for the education of all handicapped children, and to assess and assure the effectiveness of efforts to educate handicapped children. ${ }^{58}$

body of any school district" to "exclude children of filthy or vicious habits, or children suffering from contagious or infectious diseases." CAL. EDUC. CoDE $\$ 48211$ (West 1978); see L.A. Daily J., Feb. 21, 1986 at 1, col. 4 and Feb. 25, 1986, $\S 2$, at 1, col. 3. The court ordered that the child be examined by a doctor specializing in AIDS to determine if he "is suffering from a contagious or infectious disease which poses a risk to other students or the school staff." Phipps, No. 47-49-81, slip op. at 1 (Cal. Super. Ct. Feb. 6, 1986). After considering the doctor's recommendation, the court found that permitting the child to remain in school "poses no danger to other students, to faculty personnel or to himself in the customary or usual school setting." Id. slip op. at 1 (Cal. Super. Ct. Feb. 28, 1986).

In Cooperman, the relevant state statute required the city Board of Education to admit all eligible children into kindergarten. N.J. STAT. ANN. § 18A:44-2 (West 1939). The court directed the Board to enforce the order of the State Commissioner of Education which required children with AIDS to be admitted to school. Cooperman, No. C-5150-85E, slip op. at 2.

50. 612 F.2d 644 (2d Cir. 1979).

51. No. 14940/85 (N.Y. Super. Ct. Feb. 11, 1986).

52. Rehabilitation Act, 29 U.S.C. § 794 (1982).

53. U.S. ConsT. amend. XIV, $\S 1$.

54. No. 84-66-W (S.D. Iowa Dec. 31, 1984).

55. 3 Educ. Handicapped L. Rep. (CRR) 553:288 (D. Md. Jan. 11, 1982).

56. No. IP 85-1192-C (S.D. Ind. Aug. 16, 1985).

57. 20 U.S.C. $\$ \S 1400-1407,1411-1426,1431-1436,1441-1444,1451-1454$ (1982) [hereinafter EAHCA].

58. 20 U.S.C. $\$ 1400$ (c) (1982). 
Under the EAHCA, handicapped children are evaluated through a state or local administrative procedure. ${ }^{59}$ This procedure often includes both parental participation and professional assessments of the children. ${ }^{60}$ The children are then placed in special education programs designed to accommodate their particular needs. ${ }^{61}$

The EAHCA is not designed to protect children with communicable diseases and it therefore offers them little assistance, even if they qualify under it as handicapped children. ${ }^{62}$ First, many children with communicable diseases do not fall within the hteral definition provided unless they are otherwise disabled in addition to having a communicable disease. ${ }^{63}$ Second, Congress probably did not intend to include such children within the EAHCA. ${ }^{64}$ Fmally, given the Supreme Court's interpretation of the EAHCA, children with communicable diseases would be severely disadvantaged if covered by the EAHCA. ${ }^{65}$

Many children with communicable diseases are not covered by the EAHCA's definition of handicap because they do not "by reason [of their health impairment] . . . require special education and related services."66 A "health impaired" child has "limited strength, vitahty or alertness due to chronic or acute health problems ... which adversely affects a child's educational performance."67 Therefore, unless a child requires special

59. 20 U.S.C. § 1412(5) (1982); see Smith v. Robinson, 104 S. Ct. 3457, 3469 (1984).

60. 20 U.S.C. § 1412(7) (1982); see Smith, 104 S. Ct. at 3469.

61. 20 U.S.C. \& 1412(5) (1982); see Smith, 104 S. Ct. at 3469.

62. At least one commentator has questioned the applicability of the EAHCA to children with communicable diseases. Using White v. Western School Corp., No. IP-85-1192-C (S.D. Ind. Aug. $16,1983)$, as an example, he observed:

While it has been possible, as White itself indicates, to argue that people with AIDS are handicapped within the meaning of these statutes, the situation is the converse of the usual contemplated by the [EAHCA]. Instead of a school board refusing to take the action required to secure a handicapped clild the means of getting an education, the board in White acted to bar the child: in the usual case, the child eannot get the appropriate education without state action-in the AIDS case, the child could not get the appropriate education because of state action. It is stretching reason to regard an action to bar a child deemed a public health threat as sinply a placement issue under the [EAHCA].

Comment, supra note 49, at 490 n.49.

63. See infra text accompanying notes 66-77.

64. See infra text accoinpanying notes 78-80.

65. See infra text accompanying notes 82-100.

66. 20 U.S.C. $\$ 1401(1)$ (1982). Handicapped children are "mentally retarded, hard of hearing, deaf, speech impaired, visually handicapped, seriously emotionally disturbed, orthopedically inpaired, or other health impaired children, or children with specific learning disabilities, who by reason thereof require special education and related services." Id. The EAHCA's definition of handicap is much narrower than that in the Rehabilitation Act, 29 U.S.C. $\S 794$ (1982). See infra text accompanying note 103.

67. 34 C.F.R. $\S 300.5(b)(7)(1985)$. "Other health impaired" children includes those

(i) having an autistic condition which is manifested by severe communication and other developmental and educational problems; or (ii) having limited strength, vitality or alertness, due to chronic or acute hcalth problems such as a heart condition, tuberculosis, rheumatic fever, nephritis, asthma, sickle cell aneunia, hemophilia, epilepsy, lead poisoning, leukemia, or diabetes, which adversely affects a child's educational performance. 
education because of her limited strength, vitality, or alertness, she is not a handicapped child under the EAHCA. ${ }^{68}$ Only those children who are also disabled in some way by, for example, being mentally retarded or having hemophelia are considered handicapped under the EAHCA. Ryan White, ${ }^{69}$ Channon Phipps, ${ }^{70}$ Baby Jane Doe, ${ }^{71}$ Oliver Ely, ${ }^{72}$ I.C., ${ }^{73}$ and the children in Carey $^{74}$ are covered by the statute. In addition to having AIDS, these children are each disabled in some way that results in himited strength, vitality, or alertness. ${ }^{75}$ The child in District 27 Community School Board is the only one discussed in this Part who does not fall within the statute. ${ }^{76}$ The District 27 Community School Board court agreed with this reading of the EAHCA, stating:

While a child with AIDS could become handicapped as a result of deterioration in his or her condition, the evidence clearly supports the determination that such children are not handicapped for purposes of [the EAHCA] merely because they have AIDS/ARC or are infected with the HTLV-III/LAV virus. To hold otherwise would be tantamount to publicly fostering the picture of such children as "damaged goods."77

Congress inost probably did not intend to include children with communicable diseases within the EAHCA simce it at no time discussed their mclusion and the policies underlying the statute would not appear to encompass the problems that such children raise. First, given the special concerns for the healtli and safety of other children that are present when children with commumicable diseases are allowed to attend public school, ${ }^{78}$ it cannot be presumed that Congress intended to include sucl cliildren without even discussing the issue and witlout providing a pro-

Id.

68. See District 27 Community School Bd. v. Board of Educ., No. 14940-85, slip op. at 66 (N.Y. Super. Ct. Feb. 11, 1986).

69. White v. Western School Corp., No. IP 85-1192-C (S.D. Ind. Aug. 16, 1985) (hemophilia).

70. Phipps v. Saddleback Unified School Dist., No. 47-49-81 (Cal. Super. Ct. Feb. 28, 1986) (hemophilia).

71. Council Bluffs Educ. Ass'n v. Council Bluffs Community School Dist., No. 84-66-W (S.D. Iowa Dec. 31, 1984) (handicapped).

72. Ely v. Howard County Bd. of Educ., 3 Educ. Handicapped L. Rep. (CRR) 553:288 (D. Md. Jan. 11, 1982) (handicapped).

73. Cooperman v. Board of Educ., No. C-5150-85E (N.J. Super. Ct. Ch. Div. Oct. 31, 1985) (neurological impairment).

74. New York State Ass'n for Retarded Children v. Carey, 612 F.2d 644 (2d Cir. 1979) (mentally retarded).

75. Under the proposal detailed in Part III, children who fall within both statutes may choose under which statute they will pursue their claims. This will allow them to avoid the requirement that they exhaust administrative remedies even if they fall within the EAHCA. See infra text accompanying notes $82-100$ for a discussion of the exhaustion requirement.

76. District 27 Community School Bd. v. Board of Educ., No. 14940-85 (N.Y. Super. Ct. Feb. 11,1986 ). This child was infected with the HTLV-III/LAV virus, but was not otherwise impaired. Id. slip op. at 8.

77. Id. slip op. at 66-67.

78. See supra note 3. 
cedure to deal with the problems of such children. Further, Congress enacted the EAHCA to ensure that handicapped children receive free public education ${ }^{79}$ and to provide funding for states' efforts to make educational opportunities available to handicapped children. ${ }^{80}$ Both purposes suggest that Congress did not take any action that could be perceived as potentially causing harm to other children. Interpreting the EAHCA to include children with communicable diseases implies that Congress meant to disregard these potential dangers without discussing then or establishing procedures to safeguard against then1. ${ }^{81}$

Moreover, interpretimg the EAHCA to include children with cominunicable diseases will not solve the problems that these children face. The Suprenie Court has held that the EAHCA is the exclusive reinedy available to any child entitled to inake a claim under it. A child must exhaust all administrative procedures, as required under the EAHCA, before he or she can pursue a claim in court under either the equal protection clause or the Rehabilitation Act. ${ }^{82}$ In two recent district court decisions, White v. Western School Corp. and Ely v. Howard County Board of Education, the courts arrived at conflicting results in determining whether the children had in fact exhausted state administrative procedures under the EAHCA. ${ }^{83}$

In White, although the plaintiff argued that state administrative procedures were futile, the court did not agree that the decisioninakers were biased and therefore held that the case did not fit within that exception to the exhaustion doctrime. ${ }^{84}$ Ryan White was excluded from school after

79. Smith v. Robinson, 104 S. Ct. 3457, 3468 (1984); Lang v. Braintree School Comm., 545 F. Supp. 1221, 1227 (D. Mass. 1982).

80. Smith, 104 S. Ct. at 3468-69; Loughran v. Flanders, 470 F. Supp. 110, 113 (D. Conn. 1979).

81. Of course, since AIDS cannot be casually transmitted, a more persuasive argument can perhaps be made that Congress intended to include children with AIDS within the statute while excluding children with more easily transmittable diseases, such as hepatitis or tuberculosis. Nevertheless, since Congress did not discuss persons with communicable diseases and did not provide a procedure to evaluate them, it cannot be presumed that Congress intended to include them within the EAHCA's purview.

82. Smith v. Robinson, 104 S. Ct. 3457 (1984).

83. White v. Western School Corp., No. IP 85-1192-C, slip op. at 2-3 (S.D. Ind. Aug. 16, 1985); Ely v. Howard County Bd. of Educ., 3 Educ. Handicapped L. Rep. (CRR) 553:288, :291-92 (D. Md. Jan. 11, 1982) (recognizing that exhaustion was required by the statute before the Supreme Court's decision in Smith v. Robinson that the EAHCA required a child to exhaust state administrative remedies before suing in court.)

84. There are a few established exceptions to the exhaustion doctrine. First, exhaustion is not required if it would be futile to pursue state administrative remedies. Ezratty v. Commonwealth of P.R. 648 F.2d 770, 774-75 (1st Cir. 1981). Second, in cases in which the issue is purely a matter of law and capable of being resolved without agency expertise, exhaustion is not required. Id. Third, if forcing a litigant to exhaust administrative remedies would result in severe hardship, then exhaustion is not required. Id. In New York State Ass'n for Retarded Children v. Carey, 466 F. Supp. 479 (E.D.N.Y. 1978), affd, 612 F.2d 644 (2d Cir. 1979), the district court apparently applied this exception and held that the city's plan to exclude certain retarded children who were carriers of the 
parents of other children mounted an immense effort to keep Ryan out of school. ${ }^{85}$ The court was aware that the school superintendent favored excluding the child and that the school teachers had advocated the same action in an unofficial poll. ${ }^{86}$ The court, however, intimated that perhaps these school officials would change their positions after they reviewed the extensive evaluation data that they would receive pursuant to the state administrative procedures. ${ }^{87}$ In holding that the administrative process was not futile, the court emphasized that it involved four decisionmaking and reviewing tiers. The school superintendent only had a voice at the two lowest tiers, and the teachers did not have a voice at any of the levels. ${ }^{88}$ The court did not address any of the other exceptions to the exhaustion requirement, even though the exception mvolving severe hardship to the hitigant may have been appropriate due to the short life expectancy of the plaintiff. ${ }^{89}$

In $E l y$, on the other hand, the court reached the inerits of the case, finding that the case came within two of the exceptions to the exhaustion requirement, extreme hardship and futility. ${ }^{90} \mathrm{~A}$ child who was a carrier of the hepatitis-B viral antigen sought to remain in school after the local board of education excluded him. First, on hardship grounds, the court found that the removal of the child from school "will have a negative impact on [his] educational and social process, and could also result in his dismissal from ... [his] residential home which has no facilities to handle residents during school hours." 11

As an alternative basis for its decision that it had jurisdiction to address the merits of the case before the child exhausted administrative remedies, the Ely court concluded that the administrative process would

hepatitus-B virus from school violated the EAHCA. Id. at 486. The court recognized that the EAHCA required "an administrative determination of the appropriate placement of the child before any judicial review is to be taken," but concluded that "[u]nder the circumstances of this case, where time is of the essence in insuring that the mentally retarded children are provided with adequate programs . . . it [is] unwarranted to defer to administrative enforcement of the statute, as might otherwise be required." Id. The court decided that this action was necessary because the city excluded the children with only last minute notice to the children and put off a hearing for two months. Id. A fourth exception exists in cases in which the state administrative remedy is inadequate. E.g., McNeese v. Board of Educ., 373 U.S. 668 (1963). There may also be a fifth exception when the action has been brought under the Civil Rights Act, 42 U.S.C. $\$ 1983$ (1981). See discussion in P. BATOR, P. MishKin, D. Shapiro \& H. WechSLER, HART \& WechSLER, ThE Federal Courts AND THE Federal SYSTEM 983-85 (2d ed. 1973).

85. See supra note 1.

86. White, No. IP 85-1192-C, slip op. at 4 (S.D. Ind. Aug. 16, 1985).

87. Id.

88. Id. at 4-5.

89. See supra note 84 .

90. Ely v. Howard County Bd. of Educ., 3 Educ. Handicapped L. Rep. (CRR) 553:288 (D. Md. Jan. 11, 1982).

91. Id. at 292. 
have been futile. ${ }^{92}$ The local board of education had clearly expressed its intention to dismiss the child from school under its emergency powers. ${ }^{93}$ State regulations provided that once a decision is made that an emergency exists, it is not reviewable until a hearing is held. ${ }^{94}$ The court found that the hearing would be futile because it would come after the child was excluded, leaving him with "no immediate avenue of administrative rehef." 95

State administrative procedures under the EAHCA are fairly time consuming. Federal regulations give local agencies forty-five days to make a decision regarding a child's placement in school. ${ }^{96}$ Then state agencies have thirty more days to review the prior decision. ${ }^{97}$ Hearing or reviewing officers can grant extensions at the request of either party. ${ }^{98}$ Children can be compelled to miss over two months of school under the federal regulations. On several occasions state administrative procedures have dragged on for unreasonable lengths of time. ${ }^{99}$

Given the exhaustion requirement and the lengthy administrative procedures, children with soine communicable diseases would be severely disadvantaged instead of protected if they were included under the EAHCA. While the requirement of exhaustion of administrative remedies comports well with the statutory scheine that seeks to gain for handicapped children benefits otherwise unavailable, the requirentent imposes siguificant hardships on children with AIDS who have been excluded from school. AIDS is always fatal within a few years unless and until a cure or treatment can be developed. Thus it is unduly burdensome to force children with AIDS to exhaust administrative procedures before they can have their cases finally resolved in court. In the case of Ryan White, this burdensome requirement caused him to miss over a year of school. ${ }^{100}$

Children with communicable diseases are not sufficiently protected by the EAHCA. Many of thein do not fall within its literal definition of

92. The court recognized that the author of the EAHCA, Senator Harrison Williams, " 'underscore[d] that exhaustion of the administrative procedures established under this part should not be required ... in cases where such exhaustion would be futile either as a legal or practical matter.' " Id. (quoting from 121 CoNG. REC. 37416 (1975)).

93. Ely, 3 Educ. Handicapped L. Rep. at 292.

94. Id.

95. Id.

96. 34 C.F.R. $\$ 300.512$ (a) (1986).

97. 34 C.F.R. $\$ 300.512$ (b) (1986).

98. 34 C.F.R. $\$ 300.512(c)(1986)$.

99. See, e.g., Muth v. Wilburn, No. 84-2032 (E.D. Pa. Aug. 28, 1986) (state administrative procedures required over one year).

100. "The Ryan White case in Indiana is even more unsettling, because of what appears to be a cynical sense on the part of the school officials and their lawyers that time is on their side." Comment, supra note 49, at 518 n.215. "For a child with AIDS who wants a last brief chance to lead a normal life, the foreclosure of the availability of a preliminary injunction based on the 
handicapped children unless they are also otherwise disabled. Moreover, Congress probably did not intend to include children with communicable diseases within the EAHCA. Further, given the Supreme Court's interpretation of the EAHCA's exhaustion requirement, children with communicable diseases would be disadvantaged if they were included under it.

\section{B. The Rehabilitation Act}

The Rehabilitation Act ${ }^{101}$ provides that:

No otherwise qualified handicapped individual in the United States, as defined in section 706(7) of this title, shall, solely by reason of his handicap, be excluded from the participation in, be denied the benefits of, or be subjected to discrimination under any prograin or activity receiving Federal financial assistance. ${ }^{102}$

Section 706(7)(B) defines a "handicapped individual" as "any person who (i) has a physical or mental impairment which substantially limits one or more of such person's major life activities, (ii) has a record of such an impairment, or (iii) is regarded as having such an impairment."103 In two recent cases involving children with communicable diseases, $\mathrm{New}$ York State Association for Retarded Children v. Carey ${ }^{104}$ and District 27 Community School Board v. Board of Education, ${ }^{105}$ the courts relied on the Act. Although the courts in both Carey and District 27 Community

likelihood that he will prevail, the traditional police action remedy, is often dispositive of the merits." Id. at 491 n. 49 .

The EAHCA contemplates that the child would remain in school during the pendency of administrative proceedings in most cases within the statute's scope:

During the pendency of any proceedings conducted pursuant to this section, unless the

State or local educational agency and the parents or guardian otherwise agree, the child shall remain in the then current educational placement of such child, or, if applying for initial admission to a public school, shall, with the consent of the parents or guardian, be placed in the public school program until all such proceedings have been completed.

20 U.S.C. $\$ 1415(\mathrm{e})(3)(1982)$. Although the statute requires that the child remain in school while the administrative proceedings take place, if the child is perceived as a public health threat, then the state can use its police power to keep the child out of school temporarily.

101. 29 U.S.C. $\$ \S 701-796$ (1982) [hereinafter the Act].

102. Id.

103. Id. $\S 706(7)(B)$. Federal regulations adopted pursuant to the Act define "physical or mental impairment" as

(A) any physiological disorder or condition, cosmetic disfigurement, or anatomical loss affecting one or more of the following body systems: neurological; musculoskeletal; special sense organs; respiratory, including speech organs; cardio-vascular; reproductive, digestive, genito-urinary; hemic and lymphatic; skin; and endocrine; or (B) any mental or psychological disorder, such as mental retardation, organic brain syndrome, emotional or mental illness, and specific learning disabilities.

34 C.F.R. $§ 104.3(j)(2)(i)$ (1985). Major life activities are defined as "functions such as caring for one's self, performing manual tasks, walking, seeing, hearing, speaking, breathing, learning and working." 34 C.F.R. $\$ 104.3(j)(2)(i i)(1985)$.

104. 612 F.2d 644 (2d Cir. 1979).

105. No. 14940/85 (N.Y. Super. Ct. Feb. 11, 1986). 
School Board stated that excluding the children from school would violate the Act, ${ }^{106}$ they determined that the Act was applicable for different reasons.

The forty-eight children involved in Carey were mentally retarded carriers of liepatitis-B. The New York City Board of Education excluded the cliildren from school after a special education teacher developed what later turned out to be a different strain of the lepatitis virus. The court held that the children had to be readmitted to school, concluding that the children were handicapped within the ineaning of section 706(7) because they were mentally retarded. Since the city made "no effort ... to identify and exclude normal children who were carriers," and "only inentally retarded youngsters who were carriers . . . were isolated," the children "were excluded froin regular public school classes and activities 'solely by reason of their handicap' [and the Act] is thus fully applicable to this case." 107

The Carey court did not need to address the question of whether persons with commumicable diseases might also fall within the definition of handicapped under the Act: the children were inentally retarded and the court found that their inental retardation was the reason for their exclusion. ${ }^{108}$ The District 27 Community School Board court, on the other liand, addressed this question directly and decided that the child was handicapped, and thus covered under Section 706(7)(B) of the Act, solely on the basis that lie was infected witl a communicable disease. ${ }^{109}$

The District 27 Community School Board court based its conclusion that a child witl AIDS is handicapped within the Act's meaning on the federal regulations that have been proinulgated under the Act. First, the regulations define "physical or inental impairment" to inean "(A) any physiological disorder or condition ... a affecting one or nore of the fol-

106. Id. slip op. at 50-56; Carey, 612 F.2d at 649. In a recent district court decision, Thomas v. Atascadero Unified School District, No. CV 86-06609 AHS (C.D. Cal. Nov. 17, 1986), the court held that a school was required to readmit a child even though he had bitten another child in a school fight. The court concluded that "the Rehabilitation Act which prohibits discrimination against qualified handicapped persons is truly the thrust of the complaint here and also that which provides relief for the plaintiffs." Id. slip op. at 4. The court relied partially on New York State Ass'n for Retarded Children v. Carey, 612 F.2d 644 (2d Cir. 1979).

107. Carey, 612 F.2d at 649.

108. Id.

109. The District 27 Community School Bd. court decided the case assuming that the child in question had AIDS. After the trial and before the court published its opinion, a panel of medical experts concluded that the child did not have AIDS, although he had been infected with the HTLVIII/LAV virus. The court decided to write its opinion as if the child had AIDS and declined to hold the case moot because it had already considered the issues and "particularly since they are likely to recur, and are of sufficient public importance and interest." District 27 Community School Bd. v. Board of Educ., No. 14940/85, slip op. at 8 (N.Y. Super. Ct. Feb. 11, 1986).

For a discussion of whether persons with communicable diseases should be included in the Act's definition of "handicapped," see text accompanying notes 126-29. 
lowing body systems: . . . hemic and lymphatic . . ."110 The court reasoned, "Since HTLV-III/LAV destroys certain lyınphocytes, a person with AIDS clearly has such a 'physical impairment." "111 Second, the regulations define the phrase "is regarded as having an impairment" to mean any person who "is treated ... as having such an impairment."112 The court reasoned that if students with AIDS were automatically excluded froin school, they would be treated as having an impairment. ${ }^{113}$

As apphed to children with AIDS, the Act has problems similar to those encountered under the EAHCA. First, Congress did not intend to protect persons with communicable diseases under the Act. ${ }^{114}$ Second, the Act provides no substantive standards helpful in determining

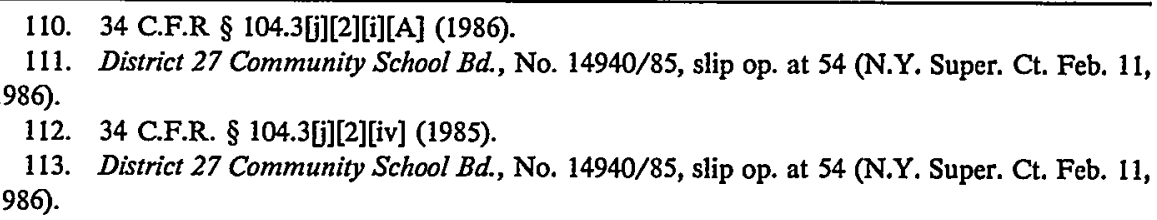

114. See infra text accompanying notes 117-25. The Department of Justice has issued a legal opinion interpreting the Act. The Justice Department's view is that if a person with AIDS is discriminated against solely because he has the disease, then the discrimination is illegal. Pear, Rights Laws Offer Only Limited Help on AIDS, U.S. Rules, N.Y. Times, June 23, 1986, at A1, col. 2. If, however, a person with AIDS is discriminated against because of concern that he will spread the disease, then the discrimination is legal under the Act. Id. If courts follow the Justice Department's view, persons with AIDS will be effectively unprotected by the Act. Employers and school boards will only have to contend that fear of contagion was a reason for their discrimination against a person with AIDS in order to insulate their actions against legal challenge. The Justice Department's opinion emphasizes, "It is important to keep in mind that [the Act] is limited to the prevention of discrimination based solely on handicap. It does not reach other forms of discrimination, and it certainly is not a general prohibition against irrational decision-making by employers or others." Id. at A13, col. 1 (emphasis added). See also Memorandum of Assistant Attorney General Charles J. Cooper, General Counsel of the Department of Health and Human Services (reported in Bureau of National Affairs, Daily Labor Report No. 122, at D1-D16 (June 25, 1986)) (administrative law judge of the California Department of Fair Employment and Housing issued proposed decision recommending dismissal of a charge that an employer discriminated based on AIDS, apparently adopting the Justice Department's analysis of the Rehabilitation Act).

Although persons with communicable diseases are not within the scope of the EAHCA or the Act, they may be protected under several state statutes. Smith, Schoomaker \& Kleinman, supra note 6. In Shuttlesworth v. Broward County Office of Budget and Management Policy, No. 85-0624 (Fla. Comm. Hum. Rels. Dec. 11, 1985), the Florida Commission on Human Rights ruled that a county employec, fired because he had AIDS, was unlawfully discriminated against. The Commission stated that AIDS is a handicap "based upon the plain meaning of the term "handicap." The Commission also concluded that a person with AIDS is within the coverage of the Florida Human Rights Act of 1977 because such person "does not enjoy, in some manner, the full and normal use of his sensory, mental or physical facilities." Id.; see also Cronan v. New England Telephone Co., No. 80322 (Mass. Super. Ct. Sept. 16, 1986) (reported in Bureau of National Affairs, Daily Labor Report No. 179 at D1-D5 (Sept. 16, 1986)) (court concluded that definition of a handicapped person under state law that prohibits discrimination based on disability includes persons with AIDS, AIDSrelated complex, and persons who are perceived to have AIDS); People v. 49 W. 12 St. Tenants Corp., No. 43604/83 (N.Y. Super. Ct. Dec. 20, 1983) (doctor, patients and New York State Attorney General sued tenants cooperative, which refused to issue renewal lease to doctor who treated AlDS patients, relying on provision of New York Human Rights Law that prohibits discrimination on basis of disabitity in the rental of commercial space); Parry, AIDS as $a$ 
whether children with AIDS are dangerous to others, and it therefore provides no assurances to parents of healthy children. ${ }^{115}$ Finally, it does not provide an adequate remedy for children with AIDS because it requires the children to exhaust several levels of slow and lengthy administrative procedures before they find out whether they can attend school. ${ }^{116}$

Congress's statement of purpose demonstrates that it did not intend to include persons with cominumicable diseases under the Act. The Act's purpose is to "develop and iniplement, through research, training, services, and the guarantee of equal opportunity, comprehensive and coordinated programs of vocational rehabilitation and independent hiving."117 As is evident from the legislative history, Congress's goal was to facilitate the employment of handicapped individuals, and to help them live normal lives integrated into society. The Act succeeded the Vocational Rehabilitation Act." 118 The new Act changed the definition of "handicapped individual," removing all references to einployability from the definition. ${ }^{119}$ The new definition does not change the underlymg intent of Congress "that the program will remain vocationally oriented." 120 The purpose of changing the definition was to let severely handicapped individuals, who inight not have obvious vocational potential, benefit under the Act. ${ }^{121}$ The Act was designed to benefit an entirely distimct category of persons because persons with commumicable diseases such as AIDS do not necessarily require vocational rehabilitation.

The Court of Appeals for the Eleventh Circuit has reached the

Handicapping Condition-Part II, 10 Mental \& Phys. Disability L. ReP. (ABA) 1, 3-4; Cecere, Payson \& Kaynard, AIDS in the Workplace, TR1AL 40 (Dec. 1986).

115. See infra text accompanying note 126 .

116. See infra text accompanying notes 127-30.

117. 19 U.S.C. \$ 701 (1982).

118. Vocational Rehabilitation Act, 40 Stat. 617 (1918), amended by Pub. L. No. 90-99, § 1, 81 Stat. 250 (1967).

119. See supra text accompanying note 103 .

120. 119 Cong. REc. 24,571 (1973). Further support for this view of the Act's purpose is derived from examining a proposed Senate bill that was not enacted. The proposed bill would have shifted the Act away from its vocational focus. The bill provided for comprehensive rehabilitative services for individuals who do not have readily identifiable vocational goals. It was "[v]igorously opposed by the [Nixon] Administration, which contended that such a title would detract from the original intentions of the Act." H.R. REP. No. 244, 93d Cong., 1st Sess. 16 (1973).

121. The new definition reflects congressional intent to include individuals with very severe handicaps "[w] hose eventual vocational outcome may not be obvious when they first apply." 119 CONG. REC. 24,571 (1973). The reason for the changed definition is "that there are handicapped individuals whose handicaps are so severe, or because of other circumstances, such as age, that they may never achieve employment. The Committee feels that they should not be denied services." Id. Similarly, the House Committee was "convinced that a significant number of severely disabled persons could be returned to gainful employment if greater emphasis were placed on accepting such clients for services and providing them with a comprehensive array of social adjustment and training opportunities." H.R. REP. No. 42, 93d Cong., 1st Sess. 10 (1973). 
opposite conclusion, holding that persons with communicable diseases are included within the Act. In Arline v. School Board of Nassau County, ${ }^{122}$ the court held that to exclude a school teacher with tuberculosis froin coverage of the Act would be to "create an exemption ... where there is not a scintilla of evidence that Congress had any intention of doing so." The court noted:

When a fact pattern falls so neatly within the statutory and regulatory framework, and when coverage would so clearly serve to promote Congress' intent to reduce instances of unthinking and unnecessary discrimination against those who are the focus of the statute's concern, we would be hard pressed to find an exemption without further legislative direction. ${ }^{123}$

The court assumed that if Congress had not meant to include persons with communicable diseases, it would have explicitly excluded them. The court's argument front congressional silence, however, cannot support a presumption that schools and other recipients of federal financial assistance must accept persons with communicable diseases though they niay present a danger to others. It is unlikely that Congress would have approved such legislation without at least some discussion of this topic.

Congress specifically exempted from the statute's purview [a]ny individual who is an alcoholic or drug abuser whose current use of alcohol or drugs prevents such individual from performing the duties of the job in question or whose einployment, by reason of such current alcohol or drug abuse, would constitute a direct threat to property or the safety of others. ${ }^{124}$

This exclusion illustrates that Congress did, in fact, intend to exempt from the Act's protection sonie individuals who present a danger to others. While protecting physically handicapped persons does not pose a danger to other participants in federal programs, protecting certain alcohol or drug abusers could pose a danger to others if such persons were unable to control their actions. Similarly, protecting persons with communicable diseases could pose a danger to others. Congress did not exclude alcohol and drug abusers from the Act's coverage entirely, but instead required a case-by-case determination as to whether an individual's condition prevents safe and efficient job performance. ${ }^{125}$

122. 772 F.2d 759, 764 (11th Cir. 1985), cert. granted in part sub nom., School Bd. v. Arline, $106 \mathrm{~S}$. Ct. 1633 (1986). In granting certiorari in the case, the Supreme Court will probably decide whether tuberculosis is a handicap under the Act. See Ostroff, TB Sufferer Seeks Job Protection Under Handicap Bias Law, L.A. Daily J., April 22, 1986, at 23, col. 1.

123. Arline, 772 F.2d at 764. The Justice Department has issued an official opinion that the view expressed in Arline-that communicable diseases constitute a handicap under the Rehabilitation Act-is "erroneous." Pear, supra note 114, at A13, col. 1; see supra note 114.

124. 29 U.S.C. $\$ 706(7)(B)(1973)$.

125. Id. A probable reason that Congress specifically mentioned alcohol and drug abusers is 
Furthermore, the Act does not provide a statutory scheme for evaluating whether a person with a communicable disease is dangerous to others, as it does with substance abusers. ${ }^{126}$ An evaluation procedure is necessary to protect the public health and to provide assurances to alleviate parents' legitimate concerns. The absence of such a procedure is strong evidence that Congress did not imtend persons with communicable diseases to be covered under the Act.

Fimally, the Act does not provide a suitable remedy for children with commumicable diseases in part because of its relationship with the EAHCA. The Supreme Court held that if a child can sue for rehef under the EAHCA and if the remedies afforded by the EAHCA and the Act are the same, then the child must exhaust the EAHCA's administrative remedies regardless of the Act under which the child sues. ${ }^{127}$ The Court held that the EAHCA is a child's exclusive avenue for pursumg her claim because "Congress did not intend a handicapped child to be able to circumvent the requirements or supplement the remedies of the [EAHCA] by resort to the general antidiscrimination provision of [the Act]." 128 The Court further concluded that to hold otherwise would "run counter to Congress' view that the needs of handicapped children are best accommodated by having the parties and the local education agency work together to formulate an individualized plan for each child's

found in the Act's legislative history. On a number of occasions throughout its deliberations, Congress specifically discussed alcohol and drug abusers for varying reasons. See, e.g., H.R. REP. No. 244, 93d Cong., 1st Sess. 10 (1973):

The Committee was told that the Department [of Health, Education, and Welfare] ... expects to spend [millions of dollars] in the treatment of alcoholics and . . . for the rehabilitation of drug addicts. ... The Committee feels, however, given the limited number of dollars directly appropriated for vocational rehabilitation programs and the amount of resources available in other Federal programs designed to serve alcohol and drug abusers and those who are socially handicapped, that first priority should be assigned to serve those persons who are severely physically and mentally handicapped.

H.R. REP. No. 42, 93d Cong., 1st Sess. 9 (1973) ("[T] he Committee applauds the commitment of the Department of Health, Education and Welfare to attacking problems resulting from alcoholism and drug abuse.")

There are no references to persons with communicable diseases anywhere in the voluminous legislative history of the Act. Since Congress did not consider communicable diseases at any time, it makes sense that Congress would not specifieally exclude them. In addition, in enacting the 1978 amendments to the Act, which excluded alcoholics and drug abusers, Congress may have been reacting specifically to a 1977 Attorney General's Opinion that had indicated that alcoholics and drug abusers were "handicapped individuals" within the meaning of the Act. $43 \mathrm{Op}$. Att'y Gen. 12 (1977). The Arline court again reached the opposite conclusion: "Congress' failure to exclude contagious diseases from coverage when it specifically excluded alcoholism and drug abuse implies that it harbored no similar disapproval about them." Arline, 772 F.2d. at 764.

126. See supra text accompanying notes $124 \& 125$.

127. Smith v. Robinson, 104 S. Ct. 3457,3474 (1984). The Court held that the same rule also applies if the child sues under the Civil Rights Act, 42 U.S.C. $\$ 1983$ (1981), or the equal protection clause. Smith, $104 \mathrm{~S}$. Ct. at 3469-70.

128. Id. at 3473 . 
education. No federal district court . . can duplicate that process." 129 Because of the Act's requirement that children exhaust administrative remedies under the EAHCA, the objection to the EAHCA applies to the Act. Children with commumicable diseases may encounter delays in the administrative process. ${ }^{130}$ This delay is particularly unfair considering the position of children who have fatal communicable diseases like AIDS.

The Act does not provide a suitable avenue of relief for children with AIDS. Congress did not intend to protect children with communicable diseases under the Rehabilitation Act. As a result, the Act focuses on employment for severely handicapped persons and does not provide a procedure for evaluating children with communicable diseases. Parents of healthy children are understandably concerned when children with communicable diseases are admitted to school under the Act which has no evaluation procedure to assess the children's health. Children with fatal diseases like AIDS are disadvantaged under the Act because they must exhaust lengthy state administrative procedures before they find out whether they can attend school.

\section{The Equal Protection Clause}

The equal protection clause of the Umited States Constitution protects persons who suffer unjustifiable discrimination by the government. Since children with AIDS have been excluded from state public schools, these children have looked to the equal protection clause for protection. When examining state action under the equal protection clause, courts use either a rational basis test or strict scrutimy. ${ }^{131}$ Neither standard sufficiently protects children with AIDS from arbitrary state action. Under a strict scrutiny standard, courts uphold discriminatory state actions only if they are the least intrusive means of achieving a compellimg state interest. ${ }^{132}$ Courts will apply a strict scrutiny standard if the individual right at stake is fundanental or if the people discrininated against constitute a suspect class. ${ }^{133}$

It is unlikely that a court would apply strict scrutiny to children with AIDS excluded froin school. First, the Supreme Court has held that public education, the interest inplicated by such an exclusion, is not a fundamental right under the United States Constitution. ${ }^{134}$ Second, it

129. Id. at 3469.

130. See text accompanying notes 96-99.

131. San Antonio Indep. School Dist. v. Rodriguez, 411 U.S. 1, 17 (1973).

132. Plyler v. Doe, 457 U.S. 202, 217 (1982); Rodriguez at 16-17.

133. Plyler, 457 U.S. at 216-17; Rodriguez, 411 U.S. at 17.

134. Rodriguez, 411 U.S. at 35 . However, education is arguably a fundamental right under some state constitutions. Robinson v. Cahill, 62 N.J. 473, 513, 303 A.2d 273, 294 (1973); In re G.H., 218 N.W.2d 441, 445 (N.D. 1974). Furthermore, once a state chooses to provide public education, 
is also far from clear that children with diseases such as AIDS constitute a suspect class. The Supreme Court has defined a suspect class as a class "saddled with such disabilities, or subjected to such a history of purposeful unequal treatment, or relegated to such a position of political powerlessness as to command extraordinary protection from the majoritarian political process." 135 An argument might be made that children with AIDS come within this definition in that they "are precluded from the pohtical process and have been neglected by state legislatures." 136 Moreover, like children who are discriminated against on the basis of race or illegitimate status, children with AIDS are often treated unfairly because of an immutable characteristic, frequently determined at birth.

Nevertheless, most indications point the other way. Courts may be reluctant to find that children with AIDS constitute a suspect class for the same reasons that courts have been unwilling to hold that handicapped children are a suspect class. Disagreement remains as to whether handicapped children constitute a suspect class because "[u]nlike distmctions based on race or religion, classifications based on [handicap] often can be justified by the different abilities" of the handicapped and nonhandicapped. ${ }^{137}$ Distmctions made between persons who do not have communicable diseases and persons who do have communicable diseases evoke that same contention because such distmctions are arguably based on reasonable justifications. In addition, simce several states forbid discrimination against persons with AIDS, ${ }^{138}$ it is difficult to argue that children with AIDS are politically powerless and therefore part of a suspect class. Finally, since AIDS has such a short history, persons with AIDS cannot argue that they have a long history of past discrimination. ${ }^{139}$

Since it is unlikely that education is a fundanental right or that chil-

the right to an education "must be made available to all on equal terms." Brown v. Board of Educ., 347 U.S. 483, 493 (1954). Many authorities have recognized the importance of an education to every individual. See supra note 4.

135. Rodriguez, 411 U.S. at 28.

136. Fialkowski v. Shapp, 405 F. Supp. 946, 959 (E.D. Pa. 1975); accord, In re G.H., 218 N.W.2d 441, 446-47 (N.D. 1974).

137. New York State Ass'n for Retarded Children v. Carey, 466 F. Supp. 487, 504 (E.D.N.Y. 1978), quoting Gurmankin v. Costanzo, 411 F. Supp. 982, 992 n.8 (E.D. Pa. 1976), aff'd, 556 F.2d 184 (3d Cir. 1977), aff'd on other grounds, 612 F.2d 644 (2d Cir. 1979); see also In re Kirschner, 74 Misc. 2d 20, 344 N.Y.S.2d 164 (1973) (handicapped children entitled to education under the New York Constitution and the fourteenth amendment to the United States Constitution). The Supreme Court has held that mentally retarded persons are not a suspect class. City of Cleburne v. Cleburne Living Center, 105 S. Ct. 3249 (1985).

138. See supra note 114.

139. Parry, supra note 114, at 2-3. An argument can be made, however, that since persons with communicable diseases have been discriminated against for centuries, see supra text aecompanying notes 7-29, courts should be more willing to call them a suspect class. 
dren with communicable diseases are members of a suspect class, a court would apply the rational basis test in equal protection analysis. Under the rational basis standard, the court would assume that school boards have expertise in the areas of health and safety of children in public schools and would require only a minimal showing by the state to justify the state's action. ${ }^{140}$ The state must only articulate a conceivable rational basis for its action. ${ }^{141}$

In two recent cases imvolving communicable disease, the courts used an equal protection analysis and held that the cities' actions violated the children's equal protection rights. ${ }^{142}$ In New York State Association for Retarded Children v. Carey, ${ }^{143}$ the district court held that the Board of Education's plan to segregate only mentally retarded children carrying the hepatitis-B virus was discriminatory. Simce the court found that the Board tested the children solely because they were mentally retarded and then excluded them, the court did not have to reach the issue of whether children with contagious diseases are a suspect class:

even under a traditional equal protection analysis the constitutionality of the Board's proposal cannot be sustained. Among the approximately $1,000,000$ children in New York City's public school system, no other group is tested for hepatitis B, nor is any action planned to identify or take special precautions with respect to any hepatitis B carriers other than those who are retarded. Such discrimination is not justified by the evidence. Thus, we conclude that the plan-with the classification as presently provided-is without rational basis and that the application of its provisions would constitute patent discrimination in violation of the rights of the 48 carrier children to equal protection of the laws. ${ }^{144}$

The court also found it umecessary to discuss whether handicapped children were a suspect class, smce the city's actions of segregating only retarded children carrying the virus lacked rational basis. ${ }^{145}$

While the Carey court had to decide whether mentally retarded carriers of hepatitis-B were more dangerous than normal carriers of the virus in a school setting, the court in District 27 Community School

140. Plyler, 457 U.S. at 216; Rodriguez, 411 U.S. at $40,55$.

141. Rodriguez, 411 U.S. at 40.

142. The parties in several of the other cases also raised the equal protection argument, but the courts decided the cases on narrower grounds. Intervenor's Memorandum of Points and Authorities in Support of Plaintiffs/Intervenors Motion for a Preliminary Injunction and/or Declaratory Relief at 31-35, Phipps v. Saddleback Unified School Dist., No. 47-49-81 (Cal. Super. Ct. Jan. 21, 1986); Verified Complaint of Plaintiff at 5, Cooperman v. Board of Educ., No. C-5150-85E (N.J. Super Ct. Oct. 10, 1985); Complaint at 5-6, White v. Western School Corp., No. IP 85-1192-C (S.D. Ind. Aug. $3,1985)$.

143. 466 F. Supp. 479, 504 (E.D.N.Y. 1978), affd on other grounds, 612 F.2d 644 (2d Cir. 1979).

144. Id. at 504 (emphasis added).

145. Id. 
Board v. Board of Education, ${ }^{146}$ was faced with an even more complex medical question. The court had to decide "whether the exclusion of known children with AIDS without imposing a similar policy on children with ARC [AIDS-related complex] or those who are asymptomatic carriers of HTLV-III/LAV would constitute a violation of the Equal Protection clause." 147 The court emphasized the impact of education upon children's socialization processes and their intellectual and psychological well-being and, finding that there was no rational basis to exclude only children known to have AIDS, concluded that such action by the city would violate the equal protection clause. ${ }^{148}$ The court stressed, "It is difficult to conceive of a rational justification imposing a discriminatory burden on known carriers of HTLV-III/LAV while untested and unidentified carriers still remain in the classroom where they pose the same theoretical (though undocumented) risks of transmitting the virus to normal children."149 The District 27 Community School Board court recognized that education is not a fundamental right ${ }^{150}$ and did not address whether children with AIDS constitute a suspect class since it held that the exclusion of the children did not satisfy the less demanding rational basis test.

Since it is highly unlikely that these children constitute a suspect class and smce education is not a fundamental right, the exclusion from school of children with commumcable diseases will not be tested agamst the standard of strict judicial scrutmy. The rational basis test does not adequately protect children with cominumicable diseases because that

146. District 27 Community School Bd. v. Board of Educ., No. 14940-85 (N.Y. Super. Ct. Feb. 11, 1985).

147. Id. slip op. at 56. In District 27 Community School Bd., the court decided to address the issues as if the child in the case had AIDS, but since the child did not, the court admitted that its discussion was dictum. Id. slip op. at 8; see supra note 109.

Many persons who are infected with the virus that causes AIDS, HTLV-III/LAV, see supra note 2, will remain carriers of the virus but will never develop any symptoms of the disease. Comment, Fear Itself: AIDS, Herpes and Public Health Decisions, 3 Yale L. \& PoL'y Rev. 479, 506 (1985). Persons who are infected with the HTLV-III/LAV virus are just as contagious as persons with AIDS itself. Id. Current estimates are that between 5 percent and 10 percent of those infected with HTLV-III/LAV will go on to develop AIDS-related complex [ARC] or AIDS within the next five years. California Department of Health Services, ACquired IMmune Deficiency Syndrome in CAlifornia: A Prescription for Meeting the NeEds of 1990, at 9 (1986). "Only a minority of those exposed to the [HTLV-III/LAV] virus will go on to develop 'full-blown AIDS.' "' D. ALTMAN, supra note 3, at 56. Approximately five to nineteen percent of persons who are infected with the HTLV-III/LAV virus go on to develop ARC, AIDS-related complex. A. G. FeTTNER \& W. CheCK, The Truth ABout AIDS 179 (1985). Approximately five to ten percent of persons with ARC go on to develop full-blown AIDS. CALIFoRNIA Department of Health Services, Acquired immune Deficiency Syndrome in CALIForNiA: A PRescription for MeEting the NeEdS of 1990, at 9 (1986).

148. District 27 Community School Bd., slip op. at 57.

149. Id. slip op. at 59.

150. Id. slip op. at 57. 
standard is extremely deferential to state interests. ${ }^{151}$ Under that standard it is even possible to argue that the public's fear of communicable disease itself provides a rational basis for discrimination. ${ }^{152}$ Another difficulty with the equal protection approach is that the pursuit of constitutional claims in court is a slow, drawn-out process. Reliance on that provision alone means that children with AIDS will be effectively deprived of an education with their peers in the ineantime.

As this Part has shown, none of the existing avenues of redress adequately protects the needs of children with fatal communicable diseases. A statute that will address the unique problems of these children is necessary. Any statute offering protection to children with communicable diseases must provide an expedited process for children who may have only a short time left to live. In addition, such a statute must take into account both the child's right to education and the public's interest in safe schools.

\section{III}

\section{The Proposal}

This Part proposes a federal statute that will deterinine who should decide whetlier a clild with a fatal communicable disease should be permitted to attend school and what factors should be considered in that decision. The purpose of the proposed statute is to protect the public lealtli while providing children with a quick decision on whether or not they can attend scliool. The statute gives children with fatal communicable diseases excluded from school a federal cause of action while giving states the option of establishing an administrative body that conforins exactly to the substantive and procedural specifications set forth in the statute. ${ }^{153}$ This Part sets out the proposed statute, and then explains the statute's scope, benefits, and procedural and substantive requirements.

\section{A. The Statute}

The proposed statute is as follows: ${ }^{154}$

(1) A child with AIDS or a similar disease who is excluded from school or any person who seeks to exclude such a child froin school may initiate proceedings before a state board which shall have exclusive jurisdiction to determine whether or not such a child should be excluded from scliool.

151. Plyer, 457 U.S. at 216 ; Rodriguez, 411 U.S. at 17, $40,55$.

152. See supra note 114 for discussion of the Department of Justice's view that fear of communicable disease may be sufficient to justify discrimination against persons with AIDS.

153. Although the statute is proposed as a federal statute with state administrative procedures, it could also be enacted as a state statute with corresponding local administration procedures.

154. The proposed statute will be referred to as the Statute. 
(2) The board shall render a decision within four weeks after the claim has been filed. In rendering a decision, the board, or the court, in the event that a state does not establish an administrative procedure that complies exactly with the substantive and procedural statutory requirements, must consider the following factors:

(a) Individual characteristics of a child that, when considered with the child's commumicable disease, present danger to the health of other students;

(b) Relevant characteristics of the other students that, when considered with a child's commumicable disease, present danger to the health of other students;

(c) The degree of certainty and unamimity among medical experts regarding the risk that the disease can be spread by casual contact; and

(d) Whether there are any less restrictive means than exclusion to protect against the risk of contagion.

(3) In rendering a decision, the board, or the court in the event that a state does not establish an administrative procedure that complies exactly with the substantive and procedural statutory requirements, may not consider the following factors:

(a) A child's hikely life expectancy;

(b) The possibility that a child with AIDS or a similar disease will be ostracized or discriminated against at school; or

(c) The possibility that a child with AIDS or a similar disease, because of his or her lack of immumity or other weak health condition, will be in increased danger at school.

(4) "A child with AIDS or a similar disease" includes only persons attending or who seek to attend a public nursery school, kindergarten, elementary school, middle school, high school, college, or university who have AIDS, ARC, or another communicable disease that is always fatal within approximately five years from the time it is identified.

(5) The board shall consist of five local physicians appointed by the state department of health. The state department of health shall establish general districts and appoint boards for each district.

(6) Each state shall use its existing procedures for appealing state agency decisions to state courts.

(7) Board decisions shall be made by majority vote.

(8) If a state establishes an administrative procedure that exactly complies with the substantive and procedural statutory requirements, a child with AIDS or a similar disease shall not have a statutory federal cause of action, and the board shall have exclusive jurisdiction of the claim.

(9) If a state does not establish an administrative procedure that 
exactly complies witl the substantive and procedural statutory requirements, then a child with AIDS or a similar disease shall have a federal cause of action under this statute, and the courts are required to comply exactly with all of the substantive specifications of this statute.

(10) A child lias the burden of proving that he or she has AIDS or a similar disease.

\section{B. The Statute's Scope}

The primary justification for instituting a separate administrative regime for children witl AIDS or similar diseases is their need for an expedited process because they are dymg. Since very few of the children carrying the HTLV-III/LAV virus eventually develop and die from AIDS, ${ }^{155}$ they are not included witlim the Statute's coverage.

The Statute also does not cover persons with AIDS or similar diseases who have been excluded from government programs other than schools, sucli as government employment and housing. School presents a situation wortlyy of special regulation for several reasons. First, discrimination im government programs such as employment and housing are already regulated. ${ }^{156}$ In contrast, there are no federal statutes available to deal with the problem of children witl fatal communicable diseases in public scliools. ${ }^{157}$ This Statute is directed solely at this problem. Second, attending scliool is a unique part of the socialization process that children should experience. ${ }^{158}$ When children are excluded from public school they may have no other alternative than to learn at home. Third, healtly children's parents have legitimate expectations that since their children are required to attend school, the scliool environment will be safe. ${ }^{159}$ It is commonly believed that diseases spread quickly and easily among children. ${ }^{160}$ One purpose of the Statute is to ensure that parents' legitimate concerns, unique to the school environment, are met.

\section{The Statute's Benefits}

There are many advantages to a federal statute dictating substantive and procedural requirements to state officials im this area. First, the Statute permits local officials to make the decisions, which comports with

155. See supra note 147.

156. See, e.g., Title VII of the Civil Rights Act of 1964, 42 U.S.C. $\S 2000 \mathrm{e}$ to $2000 \mathrm{e}-17$ (1982);

Fair Housing Act, 42 U.S.C. $\S \S 3601-3631$ (1982).

157. See supra text accompanying notes 58-129.

158. See supra note 4.

159. Schools are places where children, especially young children, share food and play roughly. These activities often involve unsanitary exchanges of body fluids, which can spread certain communicable diseases. See supra note 2. Parents may also be concerned that healthy children will not be careful or aware enough to avoid these activities.

160. See, e.g., Stone v. Probst, 165 Minn. 361, 365, 206 N.w. 642, 644 (1925). 
federal policy in favor of giving local officials primary authority over local public school affairs. ${ }^{161}$ Second, while local officials will make the decisions, they will not be unduly influenced by public pressure to exclude the children. Rather, local officials will be able to shift some of the responsibility onto the federal government simce they will be constrained by federal requirements contained in the Statute. Third, the statute will increase uniform treatınent of similar cases and will tend to dilute local biases.

There are several reasons why a streamlined administrative procedure for deciding the children's cases will be inore effective than sending the cases to courts immediately. First, local administrative decisions will be governed by strictly enforced uniform criteria, and therefore the procedures will be less disparate than court decisions without the Statute. Second, seeking relief through the overburdened court system is a timeconsuming process, while the administrative procedure will lave statutorily miposed time restramts. Third, since most judges are not experts on communicable diseases, a body of experienced pliysicians can better understand and evaluate technical medical testimony and evidence. Fourtl, pursuing claims througli the administrative procedure will require less time and effort by lawyers, thereby reducing costs.

\section{Procedural Requirements}

The local decisionmaking body will consist of five medical physicians appointed by the state department of health. ${ }^{162}$ The board will be coinprised of ouly physicians, rather than mcluding representatives of other groups, such as parents, social workers, and teachers. The composition of the board will increase the integrity of decisions and enhance the public's perception that decisions are based solely on medical expertise and not on political pressures. Their decisions will be inore accurate because doctors are well-qualified to understand the significance of medical studies and reports. They also are inore likely to be familiar witl the most current medical information. The menibers of the board will be appointed as soon as the state adopts the statutory sclieme, but the board will only sit as needed. The state board of health will establish general districts, appointing boards for each district. Board decisions will be niade by majority vote. ${ }^{163}$

The board will have to coinply with several procedural requireinents. The board will operate under strict time restraints. The board must decide whether cases are witlin its jurisdiction, hold hearings, question witnesses, review relevant needical evidence, and issue decisions

161. See, e.g., Smith v. Robinson, 104 S. Ct. 3457, 3469 (1984).

162. Statute, supra text accompanying note $154, \S 5$.

163. Id. $\S 7$. 
within four weeks from the date cases are first brought before them. ${ }^{164}$ In addition, board decisions will be subject to judicial review in the state courts pursuant to each state's statutes which provide for appeals of agency decisions to the courts. ${ }^{165}$

Cases may come before a board in several different ways. Children can bring their cases to the board when they have been excluded from school. Similarly, anyone seeking to exclude children with AIDS or a similar disease from school, including school officials, parents' groups, and teachers' associations must also bring their complaints to the board. ${ }^{166}$ The burden is on the child wishing to benefit from the Statute's protection to prove that she has a communicable disease such as AIDS. ${ }^{167}$

\section{E. Substantive Requirements}

The Statute requires that the board balance the child's right to attend school against the rights of others to be free from any danger that the child with AIDS might present. The Statute balances four factors. The board is required to consider each one in deciding whether a child with AIDS or a similar disease should be excluded. ${ }^{168}$ First, the board is required to consider any relevant individual characteristics of the child involved. For example, certam diseases may be spread through saliva and blood; therefore, the board should consider whether a child has a history of aggressive behavior such as biting and scratching. ${ }^{169}$ The

164. Id. $\S 2$.

165. See, e.g., Cal. Gov't Code § 11523 (West 1980); N.Y. Civ. Prac. L. \& R. §5601 (McKinney 1978).

166. Some persons seeking to exclude such children might allege that the children are being excluded for a different reason in an effort to escape the board's jurisdiction. In these cases, a child need only prove that he or she has AIDS or a similar disease in order to remove the case from courts' to the board's jurisdiction. Statute, supra text accompanying note $154, \S 8$.

167. Id. $\S 10$. The Statute places the burden on the child because the child has easier access to information about her own health than do school officials. If the state were required to establish the child's physical condition, the state would have to compel the child to undergo a blood test and a medical examination. These measures are both very intrusive.

168. Statute, supra text accompanying note $154, \S 2$.

169. Most scientists doubt that saliva can carry infectious levels of the HTLV-1II/LAV virus, but they cannot rule out the possibility. San Francisco Chron., Sept. 22, 1986, at 2, col. 1. Ryan Thomas, a 5-year-old boy from California with AlDS, was excluded from kindergarten because he bit another boy during a classroom scuffle. San Francisco Chron., Sept. 11, 1986, at 1, col. 2. The bite did not break the other boy's skin. San Francisco Chron., Sept. 13, 1986, at 4, col. 1. Ryan's parents contend that the biting incident was unique and that Ryan has never been a biter. San Francisco Chron., Oct. 8, 1986. A committee composed of doctors, parents, and teachers recommended "a complete psychological and educational assessment to determine if kindergarten is the place for [Ryan] to be." Id. After reviewing a confidential psychological report on Ryan Thomas, the local Board of Education excluded him from school. Keane, Boy With AIDS Belongs in School, Parents Say, San Francisco Chron., Oct. 8, 1986, at 2, col. 4. Ryan's parents sued to require the school to readmit him. A district court ordered the school to readmit Ryan under the Rehabilitation Act. Thomas v. Atascadero Unified School District, No. CV 86.06609 AHS (C.D. 
board can require children to submit relevant doctors' evaluations. ${ }^{170}$ Second, the board must consider any relevant characteristics of the other children or the staff at the school that the child with the disease would attend. For example, if other children are physically handicapped and unable to control their bodily functions, and as a result classroom conditions are unsamitary, then the board must consider the ways in which the disease is transmitted and decide whether it is safe to let the child attend. ${ }^{171}$ Third, the board must consider the degree of certainty and unanimity among medical experts regarding the risk that the disease could be spread by casual contact. Fourth, the board is required to consider whether there are less restrictive alternatives than excluding the child that could reduce the risk of contagion. For example, samitary measures might be miplemented, such as requiring children to wash more often or requiring teachers to wear rubber gloves when changing diapers or cleaning bloody injuries. ${ }^{172}$

After considering the first two factors, the individual characteristics of the child with AIDS or a similar disease and any relevant characteristics of other children or staff at the school that the child would attend, the board can decide whether the child presents a danger to others in a school setting. The board will then evaluate the danger in liglit of the third factor, the certainty and unanimity among medical experts regarding the risk that the disease could be spread through casual contact. If the board decides that the child should be excluded from school, it must also consider the fourth factor, whether there are less restrictive alternatives than exclusion that could reduce the risk of contagion.

There are three factors that the board may not consider when deciding whether a child should be excluded from school. First, the board may not take into account how long a child with AIDS or a similar disease is likely to live. ${ }^{173}$ This factor could be given far too muclı weight and unjustifiably overpower all of the other factors in the balance, giving the board an easy escape from a difficult decision. The Statute assumes that a child with AIDS or a similar disease has the same right to an education as other children so long as she does not present a danger to others. If, after balancing the other factors, the board determmes that a child

Cal. Nov. 17, 1986). See also Kirp, Hard Lessons, San Francisco Examiner Magazine 24 (Jan. 25, 1987) (describing the circumstances surrounding the district court's decision).

170. As in cases such as Council Bluffs Educ. Ass'n v. Council Bluffs Community School Dist., No. 84-60-W (S.D. Iowa Dec. 31, 1984), Cooperman v. Board of Educ., No. C-5150-85E (N.J. Super. Ct. Oct. 31, 1985), and District 27 Community School Bd. v. Board of Educ., No. 14940-85 (N.Y. Super. Ct. Feb. 11, 1986), the board or court would protect the child's identity.

171. The court in Ely v. Howard County Bd. of Educ., 3 Educ. Handicapped L. Rep. (CRR) 553:288, :289 (D. Md. Jan. 11, 1981), considered the possible effects on the staff, many of whom were pregnant women, if a child identified as a carrier of hepatitis were allowed to attend school.

172. See infra note 186.

173. Statute, supra text accompanying note $154, \S 3(\mathrm{a})$. 
presents virtually no danger to others in a school setting, the board must admit the child.

Second, the board cannot let its concern that a child with AIDS or a similar disease will be ostracized or discrimmated against influence its decision. ${ }^{174}$ Although the child will undoubtedly be treated as an outcast by some persons, others will treat the child with warmth and sympathy. ${ }^{175}$ If a child is willing to withstand the fear and hostility of soine persons at school to gain the benefits of attending school, then the board should not substitute its judgment by telling the child she cannot attend school because she will be shunned by others. ${ }^{176}$

Third, the board cannot consider the possibility that the child will be in increased danger in school because of her lack of immunity or other weak health condition. ${ }^{177}$ Although children who are blind or otherwise handicapped are in greater danger than other children in school, existing federal statutes encourage them to attend school. ${ }^{178}$ Children with AIDS or a similar disease should be able to make their own choices about whether attending school with their peers is worth the increased danger and risks.

Two of the recent cases addressing whether children with communicable diseases can be excluded from public school are instructive here because of their frank assessments of the risks mvolved and the factors considered. ${ }^{179}$ These two cases were decided using a preliminary injunction balancing test. ${ }^{180}$ Courts grant preliminary injunctions when they

174. Id. §3(b). The Supreme Court has held that ostracism and even violent antagonism cannot justify encroaching on protected rights. Cooper v. Aaron, 358 U.S. 1, 16 (1958) ("[L]aw and order are not here to be preserved by depriving the Negro children of their constitutional rights."). But see Council Bluffs Educ. Ass'n v. Council Bluffs Community School Dist., No. 84-66-W, slip op. at 4 (S.D. Iowa Dec. 31, 1984) (court follows medical expert's advice that "even though there is no real reason to isolate Baby Jane Doe on a scientific basis" when she has herpes lesions, "it is desirable on a social basis because possible contact with herpes or the mention of it usually creates such an emotional situation as to require that the child be segregated based only on social considerations."); District 27 Community School Bd. v. Board of Educ., No. 14940-85, slip op. at 21 (N.Y. Super. Ct. Feb. 11, 1986) (administrative panel recommends that child who "was physically and emotionally capable of attending school" should "consider alternative educational opportunities" because "the confidentiality concerning that child's illness had been brcached.").

175. Students in Swansea, Massachusetts supported the school superintendent's decision to let a 15- year-old junior high school boy with AIDS attend school. Silas, Is School for All?, 71 A.B.A. J. 18,19 (1985).

176. Some children whose identity and type of illness are known to the community, such as Channon Phipps and Ryan White, decided to attend school anyway.

177. Statute, supra text accompanying note $154, \S 3$ (c).

178. See discussion of the EAHCA, supra text accompanying notes 58-100.

179. Council Bluffs Educ. Ass'n v. Council Bluffs Community School Dist., No. 84-66-W (S.D. Iowa Dec. 31, 1984); Ely v. Howard County Bd. of Educ., 3 Educ. Handicapped L. Rep. (CRR) 553:288 (D. Md. Jan. 11, 1981).

180. In Phipps v. Saddleback Unified School Dist., No. 47-49-81 (Cal. Super. Ct. Feb. 28, 1986), the state court granted a preliminary injunction enabling the child to remain in school. The decision 
conclude that quick action is necessary. This test involves consideration of

(1) the threat of irreparable harm to the movant; (2) the state of the balance between this harm and the imjury that granting the injunction will inflict on other parties litigant; (3) the probability that the movant will succeed on the merits; and (4) the public interest. ${ }^{181}$

After balancing the harms and the benefits to the public and the child, the two courts reached opposite results.

In Council Bluffs Educational Association v. Council Bluffs Community School District, ${ }^{182}$ a teachers' association sought a preliminary injunction to exclude a child with herpes from an Iowa preschool for handicapped children. Addressing each factor of the balancing test in turn, the court first concluded that there was "no real threat of irreparable harm" to the teachers' association, because "the possibilities of contracting herpes from [the child] ... [were] slim or none." 183 Second, since the threat of harm was shight, "the right under the law and the social advantages to [the child] outweigh the possibility of a threat of irreparable harm, and the balance falls on the side of the child."184 Addressing the third factor of the test, the court held that there was "not too inuch probability that the [teachers' association would] succeed on the inerits"185 because the threat of harm to the teachers was sinall. Fourth, the court recognized the federal and state policy in favor of providing nondiscriminatory access to school and concluded that permitting the child to reinain in school would advance the public interest. ${ }^{186}$

did not use a preliminary injunction balancing test because it was decided on state law grounds, primarily CAL. Educ. CODE $\$ 48211$ (West 1978).

181. Dataphase Systems, Inc. v. C.L. Systens, Inc., 640 F.2d 109, 113 (8th Cir. 1981).

182. No. 84-66-W (S.D. Iowa Dec. 31, 1984).

183. Id., slip op. at 6 .

184. Id. The court emphasized the derogatory effects that isolation would have on the child's progress and developinent. Id., slip op. at 5. Sinilarly, Ryan Thomas, a five-year-old boy with AIDS who bit another child during a school fight, would have been severely disadvantaged by being excluded from kindergarten. Ryan's parents wanted hin to stay in school. San Francisco Chron., Sept. 13, 1986, at 4, col. 1. Ryan's parents thought that excluding hin from school would be extremely detrimental to him: "They're hurting Ryan keeping him out of school for 10 or 12 weeks. After a semester at home [Ryan] is going to be more and inore ostracized from the school community and his friends." San Francisco Chron., Oct. 8, 1986, at 2, col. 4. Ryan's father explained that experts told the family that the optimal psychological treatment for Ryan is to treat him like a normal boy, which means sending him to school. San Francisco Chron., Sept. 22, 1986, at 2, col. I. A federal district court held that the school was required to readmit Ryan. Thomas v. Atascadero Unified School District, No. CV 86-06609 AHS (C.D. Cal. Nov. 17, 1986).

185. Council Bluffs, No. 84-66-W, slip op. at 6 (S.D. Iowa. Dec. 31, 1984).

186. Id. Nonetheless, the Council Bluffs court imposed many conditions on the child's continued attendance at school. The child was not allowed to attend school with active herpes lesions anywhere on her body, including cold sores in her inouth. The child's mother was required to examine her for lesions and fever every morning and was required personally to take her to school every day. The child was only allowed to ride the bus on the way home from school. Before 
In Ely v. Howard County Board of Education ${ }^{187}$ a child carrying the hepatitis-B viral antigen sought a prehminary injunction to remain in school where he participated in a special education program for the learning disabled. Although applying a preliminary mjunction balancing test virtually identical to the one utilized by the Council Bluffs court, ${ }^{188}$ the Ely court denied the child's motion for a preliminary injunction. The court recognized that the child would suffer hardship and mjury if the preliminary injunction were demed because "his educational program would not be as complete as it presently is and the human interaction which he now receives at the group home and at the school would likely be diminished." 189 Nevertheless, the court held that the hardship or injury to the staff, other students, and the volunteers at the school in the event they contracted hepatitis-B outweighed the harm to the child. ${ }^{190}$

The courts in Council Bluffs and Ely reached opposite conclusions because of differing assessments of the risks mvolved. In Council Bluffs, the court decided that the risk of contracting herpes from the child was minimal because the testifynig experts unanimously agreed that the child should be placed in the preschool class. ${ }^{191}$ All of the experts also agreed that simple precautions such as washiug hands "would cut down the chances of infection from active lesion herpes by $99 \% . " 192$

In $E l y$ the evidence to support the view that the disease would not be transmitted in a school setting was not as strong as in Council Bluffs nor was that view unanimously held. Some experts testified that the risk of transmitting the virus in a preschool setting would be minimal if cer-

commingling with others at school, the child was required to be examined by her mother and a school nurse. Id. at 7-8.

In two other herpes cases the judges imposed equally rigorous conditions. In Maryland, a judge required daily examinations by a nurse and barred the child from riding the school bus. The child was allowed to attend classes if his lesions could be covered, unless they were on his hands. If they were on his back he was required to wear a one-piece jumpsuit. His diapers were required to be changed in a separate room by a school official wearing a disposable gown and gloves. He was required to have a separate set of toys reserved for his sole use, which must be disinfected daily. The Ordeal of the Herpes Kids, Time 57 (Jan. 21, 1985); Wash. Post, Jan. 10, 1985, at C1, col. 2 and Jan. 13, 1985, at A19, col. 1. In California, school officials agreed to stop other children from touching the child's food, and to minimize his contact with other children in the playground. First Day of Herpes Check Turns up Nothing, United Press International, Jan. 16, 1985 (press release available on NEXIS); Herpes Girl, Associated Press, Jan. 16, 1985 (press release available on NEXIS).

187. 3 Educ. Handicapped L. Rep. (CRR) 553:288 (D. Md. Jan. 11, 1981).

188. The court applied the test as articulated in North Carolina State Ports v. Dart Containerline, 592 F.2d 749, 750 (4th Cir. 1979). Ely, 3 Educ. Handicapped L. Rep. (CRR) at :288.

189. Id. at 289.

190. Id. The court placed little emphasis on the other two preliminary injunction factors, the likelihood of success on the merits or the public interest. Id. The court primarily considered the two factors it thought "most important," which entailed weighing the harm to the movant if an injunction were not issued versus the harm to the defendants if an injunction were granted. Id.

191. Council Bluffs Educ. Ass'n v. Council Bluffs Community School Dist., No. 84-66-W, slip op. at 3 (S.D. Iowa Dec. 31, 1984).

192. Id., slip. op. at 4 . 
tain hygienic precautions were taken. ${ }^{193}$ On the other hand, the court noted that saliva carries the hepatitis-B virus and that the staff of the school frequently put their fingers in the child's mouth. As a result, the child's saliva came into contact with the staff and other children. Additionally, the court found that hepatitis-B posed a significant risk to unborn fetuses of women who contract the disease in the later term of their pregnancies and noted that the majority of employees at the school were female and that three of them were pregnant. In trying to assess the risks involved, the court expressed frustration resulting from the lack of studies regarding the "effectiveness of hygiemc precautions in these circumstances." 194 While the court admitted that hygienic precautions may reduce the risk, the court found this argument too speculative to grant the preliminary injunction. ${ }^{195}$ The court chose to exclude the child because the potential danger of keeping him in school could be "life threatening at the worst, and hfe debilitating if not life threatening." 196

As these cases show, determination of the risk involved in allowing children with communicable diseases to attend school is not easy. The Statute proposes a procedure to make this determination easier and more reliable by combining clear administrative guidelines and a board of respected local doctors.

\section{IV \\ CONCLUSION}

Children with AIDS and other diseases that are fatal within a short period of time are not adequately protected under current law. Existing constitutional and statutory provisions are not sufficiently tailored to meet the exigencies of this situation. The proposed Statute provides a comprehensive yet flexible mechanism to meet the needs of both children with communicable diseases and their healthy schoolmates.

Leah Hammett*

193. Ely, 3 Educ. Handicapped L. Rep. (CRR) at 289 (Dec. 23, 1981).

194. Id.

195. Id. at 290.

196. Id.

* A.B. 1984, University of California, Berkeley; third-year student, Boalt Hall School of Law, University of California, Berkeley. 
